DOI: $10.20472 / S S 2015.4 .1 .004$

\title{
GYPSIES AS VICTIMS OF CRIME OF CRIMES
}

\section{SERDAR ORNEK, MEHLIKA OZLEM ULTAN}

\begin{abstract}
:
Many groups such as Jews, Gypsies, Slavs or the homosexuals were labelled as 'undesirables' during the Nazi era. Jews Especially were presented as the enemy of the Aryan 'master race' according to the Nazi ideology. Even though gypsies continue to face public prejudices and discrimination today, this study will be focused on the situation and the rights of Gypsies before and after the World War II. Gypsies had full and equal rights of citizenship under the Weimar Constitution, but they were still subject to some discriminational laws. When Hitler took power in 1933, anti-Gypsy laws remained in effect. In 1939, 30.000-35.000 people known as 'Gypsies' were living in Germany and Austria. In Europe, the situation of Gypsies differed from country to country, depending on local circumstances. For example, in German-occupied Europe, Gypsies were killed, or deported to camps in Germany or eastern Europe. In Croatia, Serbia, Romania and also Hungary, thousands of Gypsies were killed during the 1940s. According to the United Nations Genocide Convention, "Genocide is a coordinated plan to destroy, in whole or in part, a national, ethnic, racial or religious group by killing, causing serious bodily or mental harm, inflicting conditions designed to bring about its destruction, preventing births within the group, or removing children from the group." Many genocides have occurred throughout history, but the word Genocide began to be used from the 1940s. 'Genocide' became a part of international law, with the 1948 United Nations Convention on Genocide. This study will try to examine the Gypsies, especially the Roma, as victims of genocide, how they were treated during the World War II and what were their rights before and after the Nazi's.
\end{abstract}

\section{Keywords:}

Genocide, Gypsies, World War II, Porajmos, United Nations Genocide Convention

\section{Authors:}

SERDAR ORNEK, Kocaeli University, Kocaeli University, Email: sedarornek@hotmail.com MEHLIKA OZLEM ULTAN, Kocaeli University, Turkey, Email: ozlemultan@gmail.com

\section{Citation:}

SERDAR ORNEK, MEHLIKA OZLEM ULTAN (2015). Gypsies as Victims of Crime of Crimes. International Journal of Social Sciences, Vol. IV(1), pp. 63-71., 10.20472/SS2015.4.1.004 


\section{Genocide in International Policy and Law}

In 1944, the term "Genocide" was first defined by Raphael Lemkin who was a Polish jurist. He described genocide by combining "genos" (as a Greek Word that means race or tribe) and "cide" (as a Latin word that means murder). According to Lemkin, the definition of genocide was: (Manaktala, 2012, p.179-180)

"A coordinated plan of different actions aiming at the destruction of essential foundations of the life of national groups, with the aim of annihilating the groups themselves. The objectives of such a plan would be disintegration of the political and social institutions, of culture, language, national feelings, religion, and the economic existence of national groups, and the destruction of the personal security, liberty, health, dignity, and even the lives of the individuals belonging to such groups."

The purpose of Lemkin was to document German war crimes. According to him, these crimes were barbarous and they should be punished by international law. Under the influence of Nazi ideology, the German state was waging war against nations. Although Lemkin coined the term 'genocide', the original conception of genocide was that of the waging of war by a state to destroy nations. (Freeman, 1995, p.209)

Jean-Paul Sartre wrote that "The fact of genocide is as old as humanity", but the law is considerably younger. (Schabas, 2009, p.1) Genocides became a part of the international policy and law since the end of the World War II. (Krain, 2005, p.363) By Lemkin's lobbying, and for legal purposes, genocide was defined by the Convention on the Prevention and Punishment of the Crime of Genocide in 1948. The definition of genocide became narrower than Lemkin's. (Campbell, 2009, p.152) According to the Convention, the definition of genocide was: (Article II, Convention on the Prevention and Punishment of the Crime of Genocide, 1948, p.2)

"Any of the following acts committed with intent to destroy, in whole or in part, a national, ethnical, racial or religious group, as such: killing members of the group; causing serious bodily or mental harm to members of the group; deliberately inflicting on the group conditions of life calculated to bring about its physical destruction in whole or in part; imposing measures intended to prevent births within the group; forcibly transferring children of the group to another group."

It would seem that the Article II of the Convention on the Prevention and Punishment of the Crime of Genocide have excluded the meaning of "ethnic cleansing" that is the forced expulsion of civilians belonging to a special ethnic, racial or religious group from an area, or village. (Van Der Wolf, 2011, p. 24)

The term of genocide has three main essential aspects about its conceptual role: First, it is supposed to reflect a distinctive phenomenon; something that is not denoted by any of the other terms that is used. Second, it is supposed to reflect a phenomenon that is, as part of its very meaning, morally wrong. It is not certain that it was morally reprehensible. It is not supposed to be intelligible to ask: it was genocide, but was it justified? Finally, it is supposed to reflect a distinctive crime and also it is distinctively heinous. (Boghossian, 2010, p.73)

Some genocide scholars determine four types of genocide: ideological genocide to fulfill an ideology or myth (the prime example of which is the Holocaust); retributive genocide to eliminate a real or potential threat; developmental genocide to eliminate 
an indigenous group impeding economic exploitation and development; and despotic genocide to spread terror. (Fein, 1999, p.45)

According to Krain (2005, p.364) genocide can be summarized as mass killing in which the victims are defined by association with a particular communal group. "Genocide is organized and unilateral mass killing on the basis of ethnicity." According to this definition, the most important part of genocide is mass killing. The second one is being organized (it is related with the capacity for collective action). The third one is being unilateral (it includes genocide, terrorism, vigilantism and rioting). (Campbell, 2009, p.153-154) And finally, genocide is related with ethnicity. It does not include killing on the basis of class or political identity. Ethnic groups included tribes, castes, language groups and nationalities that marked by race or religion. (Mann, 2005, p.11) Thus it can be said that genocide is characterized as involving great losses not only to the group targeted, but also to humanity as a whole. (Macleod, 2012, p.200)

The term "Holocaust" is seen as the general act of genocide of the Jews and the Roma, which took place under the Nazi regime during World War II. Both of them had racial grounds with the objective of their complete extermination. The regime also targeted all people who did not fit into the "Arian superior" archetype. (The Roma Genocide, 2014)

\section{Gypsies in Prewar Europe}

Roma (Gypsies) originally came from the Punjab region of northern India and entered Europe between the eighth and tenth centuries. Many Europeans thought that they came from Egypt that is why they were called as "Gypsies". During World War II, most of the Roma in Germany belonged to the Sinti and Roma family groupings. They spoke a common language that was called Romani, based on Sanskrit (the classical language of India). Both the Sinti and Roma groupings were called as "Roma", and some of the Roma preferred to be known as "Gypsies". (Roma in Prewar Europe, 2014) Most of the Sinti who resided in Germany were more assimilated into German culture and society than the Roma. (Woolford \& Wolejszo, 2006, p.872) The Gypsies were continually assimilated by the non-Gypsies who could be called as "Gaje". They tried to assimilate the Gypsies by stealing their children, placing them with other families, giving them cattle, expecting them to become farmers. Their customs and language became outlawed. They were forced to attend school and church. In 18th century, King Frederick William I of Prussia ordered all Gypsies over 18 years of age to be hanged. This indicated that laws and mandates allowed to kill Gypsies. This situation was called as "Gypsy Hunting", it was common through 18th and even 19th centuries. Though the Gypsies had undergone of such persecution, and were systematically slaughtered. (Rosenberg, 2014)

\section{Gypsies under the Weimar Republic and the Nazi}

From 1918 to 1933, under the Weimar Republic, anti-Gypsy laws became widespread. By these laws, the Gypsies were prohibited from traveling freely, and sent to forcedlabor camps. (Sinti and Roma, 2014). Many gypsies had dark skin, were nomadic, 
non-Christian, and spoke a foreign language (Romani). Because of that they seemed very different from the European people. (Rosenberg, 2014)

On the Nazi agenda and in Nazi world politics, the main racial problem was the Jewish Question. (Margalit, 2000, p.192) The Jews were regarded as the enemies of the Aryan people. Germany had other foreign races, like Gypsies, but they were less significant than the Jews. In 1933 there were about 525,000 Jews in Germany, some of them in important positions in Germany. Whereas there were 26.000 Gypsies, who represented a marginal element. (Lewy, 1999, p.202-203) The Gypsies have been invisible in historiography. However, as it can be seen in the holocaust literature, most of the experts agreed that the aim of the Nazi mass murder was not only to kill the Jews but also the Gypsies. The major difference between these mass murders was that not all the Gypsies were killed, since some of them were saved as Aryans. (Milton,1991, p.375-376) In the beginning, the Gypsies were accepted as Aryans. According to Nazi racial ideology, they were not named as a group that threatened the German people. Thus, the Nazis tried to persecute the Gypsies but they firstly must prove that they were not a part of the Aryan. (Rosenberg, 2014)

Nazi's thought that the Gypsies were not an ideological problem or a threat. However, they were an irritant, and should be treated as a plague. (Bauer \& Milton, 1992, p.514) According to Professor Hans F. K. Günther's book, Rassenkunde Europas (Anthropology of Europe), Nazi racial researchers found a reason to persecute most of the Gypsies. Günther wrote that The Gypsies have retained some of their elements from their Nordic home, but they are descended from the lowest classes of the population in that region. Through their migration, they have met with foreigners, and become an Oriental, western-Asiatic racial mixture, with an addition of Indian, midAsiatic, and European strains. (Rosenberg, 2014)

The Gypsies were the one of the victims of the Nazi ideology for racial purity. During the Nazi genocide, there were a great number of individual murders, violations of human dignity and heinous acts. (Macleod, 2012, p.197) From the 19th century, antiRoma laws began to be passed and some different institutions were established to fight with the "Gypsy plague". (The Roma Genocide, 2014) When the Nazis came to power, those laws were expanded. Gypsies were considered as the social outcasts. (Sinti and Roma, 2014). At the beginning of the nazi regime, anti-Gypsy measures had been justified on social grounds. Gypsies generally represented an asocial element. (Lewy, 1999, p.201) They deprived of their civil rights and property, their marriage to "Aryans" was prohibited, and they were deemed to be inferior by law. (Teleki 2009, p.91-92)

In order to determine who was "pure" and who was "mixed" Gypsy, to study the Gypsy problem and also to make recommendations for Nazi policy; on July 14, 1933, the Nazis established the Racial Hygiene and Population Biology Research Unit. Dr. Robert Ritter became the head of the unit. (Rosenberg, 2014) It tried to prove that most Roma posed a danger to German racial purity and should be eliminated. (The Roma Genocide, 2014) Dr. Ritter suggested that if a person had "one or two Gypsies among his grandparents" or if "two or more of his grandparents were part-Gypsies", 
he/she would be a Gypsy. Because of this designation, 18,000 German Gypsies were killed (Rosenberg, 2014)

In November 1933, the "Law Against Dangerous Habitual Criminals" was passed, and the police began arresting the Gypsies under this law. Along with the beggars, vagrants, homeless, and alcoholics that labeled asocial, the Gypsies were also arrested and interned in concentration camps. (Sinti and Roma, 2014). On September 15, 1935, the Nuremberg Laws, which was related to the Jews directly, were extended to include "Gypsies, Negroes and their bastard offspring". (The Roma Genocide, 2014) Although the Nuremberg racial laws did not mention Romani, they included Jews and Negroes as "racially distinctive" minorities with "alien blood." (Sinti and Roma, 2014). For the Gypsies, the German bureaucracy applied the miscegenation requirement of the Nuremberg laws. In 1935, the "Reich Citizenship Law" and the "Law for the Protection of German Blood and German Honor" classified Jews, Gypsies, and Blacks as having "alien blood". (Milton,1991, p.378)

Soon after these laws, the first Roma ghettos and deportation to labour camps evaluated. (The Roma Genocide, 2014) Zigeunerlager was one of the first concentration camps. Marzahn in Berlin, Lackenbach and Salzburg in Austria were the other concentration camps where hundreds of Gypsy died as a result of the horrendous conditions. (Genocide of European Roma Gypsies, 2014). From 1933 to 1939, the German police had confined many Gypsies to Zigeunerlager. It was also an embryonic ghettos. In these kind of special internment camps, scientists implemented the racial and genealogical registration of all Gypsies, which generally resulted in involuntary sterilization of Romani and Sinti prisoners. (Milton, 1991, p.378) The head of the Racial Hygiene and Population Biology Research Unit Dr. Ritter, and his assistant Eva Justin, visited the Gypsy concentration camps (Zigeunerlager) and examined that $90 \%$ of Gypsies were of mixed blood, thus dangerous. (Rosenberg, 2014)

The Nazis could not discover a "scientific" reason to kill the rest. Thus they should decide what to do with the other $10 \%$ of the Gypsies that can categorized as pure. Himmler suggested a special reservation for them. For example, nine Gypsy representatives were selected in October 1942 and told to create lists of Sinti and Romani to be saved. (Rosenberg, 2014)

In 1936, a Nazi Party proclamation indicated that the Gypsy issue was a matter of race and elimination without hesitation of the entire Gypsy population had to be instigated immediately. (Gypsies: A Persecuted Race, 2014)

By 1938, most of the German and Austrian Gypsies began to be arrested and sent to concentration camps where they had to wear black triangular patches (the symbol for "asocials") or green patches (the symbol for professional criminals) and sometimes the letter "Z." (Sinti and Roma, 2014). In the concentration camps, the Gypsies were at the bottom of the social hierarchy and were tattoed with the letter " $Z$ " for "Zigeuner". (Teleki, 2009, p.92)

\section{Gypsies during the World War II}


Since the World War II, life has remained hard for the Gypsies. In Western Europe, they were subject to racism. (Brearley, 2001, p.591) In 1939, approximately a million Gypsy were living in Europe. Half of them were in eastern Europe, especially in the Soviet Union and Romania. The other ones were living in Hungary, Yugoslavia, and Bulgaria. There were about 30,000 Roma in Germany. (Roma in Prewar Europe, 2014)

On September 21, 1939, Germany succeeded in the invasion of Poland, Reinhard Heydrich, head of the Reich Security Main Office, intended to deport 30,000 German and Austrian Gypsy from the Greater German Reich to the Generalgouvernement. (Genocide of European Roma Gypsies, 2014).

The genocide of gypsies was one of the waves of national and ethnic conflict and genocide in the wake of crashing states and empires. During the World War II, the Nazis tried to exterminate the Jews and Gypsies and committed partial genocide against other peoples. (Melson,1996, p.157)

Hitler had an obsessive preoccupation with Jews. (Margalit, 2000, p.193) In the history of the Nazi regime, the persecution of the Gypsies was one of the most neglected issues. (Lewy, 1999, p.383) Although he referred to Gypsies only twice in his Table Talks, in May 1940, Hitler determined that the Gypsies were foreigners and had to be treated like the Jews. (Margalit, 2000, p.193)

In 1941, German police authorities transported 5,000 Gypsies from Austria to the camp for Jews in Lodz, where they resided in a segregated section. Approximately $50 \%$ of the Roma died, because of not having adequate food, fuel, shelter, and medicines. In 1942, German SS and police officials deported survived Gypsies to the killing center at Chelmno. At the Lodz ghetto, the Gypsies died in gas vans, and poisoned by carbon monoxide gas. (Genocide of European Roma Gypsies, 2014).

In 1942, Himmler declared the mass deportations to Auschwitz. The Gypsy camp at Auschwitz-Birkenau was only one of the places that the Gypsies were gassed and murdered. (The Roma Genocide, 2014) Nearly 3,500 Gypsy were prisoners in other German concentration camps, such as in Ravensbrück, Natzweiler-Struthof, and Sachsenhausen. Conditions in the Gypsy camp at Auschwitz-Birkenau were caused the spread of infectious disease and epidemics, such as typhus, smallpox, and dysentery. (Genocide of European Roma Gypsies, 2014). It was estimated that hundreds of Gypsies died from epidemics, malnutrition, medical experiments, forced sterilization and forced labour in these concentration camps. (Teleki, 2009, p.92)

On November 15, 1943, Himmler suggested that the Gypsies, including people of "pure Gypsy blood" should be treated like Jews and placed in concentration camps. In Auschwitz, the Gypsies were deported to newly built "Gypsy family camp", where entire families lived together. (The Roma Genocide, 2014) The SS and police authorities incarcerated the Gypsies in forced labor camps. The conditions under which they had to live and work, were deadly. The situation of the survivors is unknown; it is possible that the SS murdered them who were still alive in the gas chamber of Belzec, Sobibor, or Treblinka. (Genocide of European Roma Gypsies, 2014). 
The Nazi persecution of the Gypsies changed from country to country and region to region, depending on local circumstances. For example, in the Balkans and the Soviet Union, mobile killing squads travelled for massacring the inhabitants and leaving no records about the number of victims. In Croatia, in Jasenovac concentration camp, tens of thousands of the Gypsies were killed. In Yugoslavia, the Gypsy Genocide was intense where around 90,000 Roma were killed. In Romania, there were not a systematically murder, but they exiled 26.000 Gypsies to Transnistria, a section of south western Ukraine placed under Romanian administration, where thousands died from disease, starvation and brutal treatment. (The Roma Genocide, 2014) In Germany, the Gypsies were deployed as forced laborers or transported to Poland to be deployed at forced labor or to be killed. In France, French police interned at least 3,000 and maybe 6,000 Gypsies. French authorities shipped some of them to camps in Germany, such as Buchenwald, Dachau, and Ravensbrück. In Serbia, the German authorities killed male Gypsies by shooting during 1941 and early 1942; then murdered the women and children in gas vans in 1942. The total number was estimated between 1,000 and 12,000. (Genocide of European Roma Gypsies, 2014). Historians estimated that 250,000 to 500,000 Gypsies (approximately three-fourths of the German Gypsies and half of the Austrian Gypsies) were murdered during the Holocaust period - an event they call the Porajmos. (Rosenberg, 2014) The Porajmos was a Romani word that means "the devouring" and was often used to explain the genocide of Roma and Sinti people committed by the Nazis. (Woolford \& Wolejszo, 2006, p.872) Porajmos in Hungary was one of the terrible losses suffered by mankind. The Gypsies were killed by gunshot, hunger, disease, mines, lethal gas, fire or poisons. Some of them were buried while still alive. Most of them were left mouldering, nameless, in mass graves at forest or in some areas. (Teleki, 2009, p.92)

After the World War II, discrimination against the Gypsies continued throughout Central and Eastern Europe. The Federal Republic of Germany accepted that all measures taken against the Gypsies before 1943 were legitimate official measures. Thus the victims of the genocide, who had been incarcerated, forcibly sterilized, and deported out of Germany for no specific crime, could not be acquitted. In 1979, the West German Federal Parliament defined the Nazi persecution of the Gypsies as being racially motivated, creating eligibility for most Roma to apply for compensation for their suffering and loss under the Nazi regime. However, most of the victims had already died. (Genocide of European Roma Gypsies, 2014).

\section{Conclusion}

The total number of Gypsies in the world (particularly in Europe) is not certain. However, it is estimated that there are 40 to 45 million people of Gypsy origin in the world, and they live in all countries of the world. Nearly 12 million Gypsy live in Europe today, most of them in Eastern Europe. (Arayıcı, 1998, p.254)

The fate of the Gypsies paralleled that of the Jews in some ways. Under the Nazi regime, the Gypsies were subjected to arbitrary internment, forced labor, and mass murder. German authorities killed thousands of the Gypsies in the German-occupied territories of the Soviet Union and Serbia and thousands in the concentration camps at 
Auschwitz-Birkenau, Chelmno, Belzec, Sobibor, and Treblinka. The SS and German police incarcerated the Gypsies in the Bergen-Belsen, Sachsenhausen, Buchenwald, Dachau, Mauthausen, and Ravensbrück concentration camps. (Genocide of European Roma Gypsies, 2014). The number of Gypsy mortality in the Porajmos was nearly the same as the number of Jewish mortality in the Holocaust. Found sources about the fate of Jews were more numerous than those about Gypsies. They included records of diplomatic negotiations, deportations, Einsatzgruppen statistics, and killing center records. (Milton, 1991, p.377)

From the Middle Ages to the present day, the Gypsies have been the target of racial discrimination and genocide. It is not possible to give a certain number of Gypsy victims because many of them were murdered by SS groups, on sight, or reached the gas chambers without even being registered officially, maybe as much as $70-80 \%$ of the total Gypsy population in Europe at the time. (The Roma Genocide, 2014) The Gypsies in Europe were sterilized, ghettoized, and then deported to concentration and death camps by the Nazis. (Woolford \& Wolejszo, 2006, p.872)

Genocide is an organized and unilateral mass killing on the basis of ethnicity. The Holocaust and the Porajmos are not the only examples of the genocide. There are some other terrible examples as well. It is certain that the damage of genocide is not only to individuals, or to collectives. Genocide damages humankind.

\section{REFERENCES}

"Convention on the Prevention and Punishment of the Crime of Genocide". United Nations Treaty Series. No. 1021. (1948). [Online] Available from: https://treaties.un.org/doc/Publication/UNTS/Volume\%2078/volume-78-I-1021-English.pdf, [Accessed: 04 September 2014].

"Sinti and Roma", (2014) [Online] Available from: http://fcit.coedu.usf.edu/holocaust/people/victroma.htm. [Accessed: 04 September 2014].

"The Roma Genocide". (2014) [Online] Available from: http://2august.eu/the-roma-genocide/. [Accessed: 04 September 2014].

ARAYICI A. (1998) "The Gypsy minority in Europe - some considerations". International Social Science Journal, 50 (156). p.253-262.

BAUER Y. \& MILTON S. (1992) Gypsies and the Holocaust. The History Teacher. 25 (4). p.513-521.

BOGHOSSIAN P. (2010) The concept of genocide. Journal of Genocide Research. 12 (1-2), p.69-80.

BREARLEY M. (2001) The Persecution of Gypsies in Europe. American Behavioral Scientist. 45 (4). p.588-599.

CAMPBELL B. (2009) Genocide as Social Control. Sociological Theory. 27 (2). p.150-172.

FEIN H. (1999) Genocide and gender: The uses of women and group destiny. Journal of Genocide Research. 1 (1). p.43-63.

FREEMAN M. (1995) Genocide, civilization and modernity. The British Journal of Sociology, 46 (2). p.207-223.

Genocide of European Roma (Gypsies), 1939-1945. (2014). [Online] Available from: http://www.ushmm.org/wlc/en/article.php?Moduleld=10005219. [Accessed: 02 September 2014].

Gypsies: A Persecuted Race (2014) [Online] Available from: http://www.chgs.umn.edu/histories/victims/romaSinti/gypsies3.html, [Accessed: 02 September 2014].

KRAIN M. (2005) International intervention and the severity of genocides and politicides. International Studies Quarterly. 49 (3). p.363-387.

LEWY G. (1999) Gypsies and Jews under the Nazis. Holocaust and Genocide Studies. 13 (3), p.383404. 
MACLEOD C. (2012) "An Alternative Approach to the Harm of Genocide". Politics. 32 (3). p.197-206.

MANAKTALA M. (2012) Defining genocide. Peace Review: A Journal of Social Justice, 24 (2). p.179186.

MANN M. (2005) The Dark Side of Democracy: Explaining Ethnic Cleansing. New York: Cambridge University Press.

MARGALIT G. (2000) The uniqueness of the Nazi persecution of the Gypsies. Romani Studies 5, 10 (2). p.185-210.

MELSON R. (1996) Paradigms of genocide: The holocaust, the Armenian genocide, and contemporary mass destructions. Annals of the American Academy of Political and Social Science. Vol. 548, p.156-168.

MILTON S. (1991) Gypsies and the Holocaust. The History Teacher. 24 (4). p.375-387.

Roma (Gypsies) in Prewar Europe. (2014). [Online] Available from: http://www.ushmm.org/wlc/en/article.php?Moduleld=10005395, [Accessed: 02 September 2014].

ROSENBERG J. (2014) "Gypsies and the Holocaust: The Story of Some of the Forgotten Victims of the Holocaust". [Online] Available from: http://history1900s.about.com/od/holocaust/a/gypsies 2.htm. [Accessed: 04 September 2014].

SCHABAS W.A. (2009) Genocide in International Law: The Crime of Crimes. Cambridge: Cambridge University Press.

TELEKI L. (2009) The Fate of the Roma during the Holocaust: The Untold History. In (Ed.) The Holocaust and the United Nations Outreach Programme. New York: United Nations Discussion Papers Journal.

VAN DER WOLF W. (2011) Genocide and International Criminal Law. The Hague: International Courts Association.

WOOLFORD A. \& WOLEJSZO S. (2006) "Collecting on moral debts: Reparations for the Holocaust and Pořajmos”. Law \& Society Review. 40 (4). p.871-902. 